\title{
Twenty-First (21st) Century Skills of College of Education Alumni
}

\author{
Gladys P. Mangiduyos, Gener S. Subia \\ College of Education, Wesleyan University Philippines, Cabanatuan City, Philippines \\ Email: gmangiduyos@gmail.com
}

How to cite this paper: Mangiduyos, G. P., \& Subia, G. S. (2021). Twenty-First (21st) Century Skills of College of Education Alumni. Open Journal of Social Sciences, 9, 330337.

https://doi.org/10.4236/jss.2021.99023

Received: July 26, 2021

Accepted: September 12, 2021

Published: September 15, 2021

Copyright (c) 2021 by author(s) and Scientific Research Publishing Inc. This work is licensed under the Creative Commons Attribution International License (CC BY 4.0).

http://creativecommons.org/licenses/by/4.0/

(c) (i) Open Access

\begin{abstract}
This study investigated employability and explored the 21st-century skills of 142 Bachelor of Elementary and Secondary Education alumni of Wesleyan University Philippines. The survey found out that respondents were largely females, batch 2014, Bachelor of Elementary Education degrees, working in public institutions, and were permanent. As to present occupation and place of work, most of them are teachers and working in the country. In terms of length of experience and monthly salary, the majority of the respondents were new in their work and earning less than P20,000 a month. The respondents were hired in their current profession because of the repute of the college where they graduated from and their scholastic level. The highly relevant 21 st-century abilities in their current profession are interpersonal and collaborative, communication, and problem-solving. Because of the excellent accreditation status and quality education of the University, the respondents feel proud that they were its graduates.
\end{abstract}

\section{Keywords}

College of Education, Communication Skills, Problem-Solving Skills, Tracer Study, Twenty-First-Century Skills

\section{Introduction}

"Recognizing the reality in today's academic world, the role of higher education institutions can not only be limited to impart knowledge but also to contribute to maintaining a competitive economy and most important of all, to secure the dream of graduates to get jobs and become socially recognized and successful in their respective field of endeavors" (Menez, 2014: p. 14).

"The alumni, especially college graduates, are considered as the best evidence of a program's effectiveness in terms of employment and positions held. Moreo- 
ver, they are a good source of feedback regarding the program's relevance in the current labor market" (Orejana \& Resurreccion, 2010). However, employment statistics in the country attest to the inability of college graduates to get employed. In 2011, according to National Statistics Office (NSO), 39\% of unemployed were those who have reached or finished college education. Even data from UNESCO showed that the global unemployment rate was $6.2 \%$ in 2010 compared to $5.6 \%$ in 2007. In January 2019, it was estimated at 5.2\%. "Of the total unemployed, the age group 15 - 24 years comprised $43.7 \%$, while the age group 25 to $34,30.6 \%$. By educational attainment, $20.9 \%$ of the unemployed were college graduates, $8.2 \%$ were college undergraduates, and $28.2 \%$ have completed junior high school. Graduates of junior high school include those high school graduates in the old curriculum" (PSA, 2019). Students today require more 21st-century skills than ever before. They not only create a foundation for successful classroom learning, but they also ensure that they can succeed in a world where change is constant and learning never stops. They are also quite crucial for the well-being of our country (Ross, 2017). This simply means that students must be taught 21 st-century abilities in order to have a better chance of being hired as employees after graduation. This is the goal of this research. The researchers looked into the employability of Wesleyan University Philippines' College of Education graduates who were educated with 21 st century abilities.

\section{Literature Review}

To thrive in today's internationally and technologically connected world, all learners, from cradle to grave, require new skills and information. Opportunities to master 21st-century skills are critical if we wish to equip our children for success in school, career, and life (Ross, 2017).

"In this century, employability skill is the most required skill besides technical knowledge in an attempt to compete for employment and sustain job at the industrial global market" (Ismail \& Mohammed, 2015). Schools must provide training that matches the requirements that employers set for their employees. Although different industries have distinct criteria, they always have a set of attributes that they expect their applicants to have in order to achieve institutional goals. Employers will always look for their criteria, whether they are looking for graduates with talents that are linked or unrelated to their field of specialty (Albina \& Sumagaysay, 2020).

"Graduate tracer studies can give useful information for analyzing the educational and training outcomes of a specific institution of higher education and it gathers crucial information about the graduates' work profiles" (Aquino, et al., 2016). Many tracer studies were conducted in various specializations such as Business Administration (Alvarez, 2020; Calma, 2019; Menez, 2014), Engineering and Information Technology (Albina \& Sumagaysay, 2020; Pontillas, 2018), Psychology and Education, Arts and Sciences (Ramirez et al., 2014; Woya; 2019). Among the many college graduate courses, teacher education is one of the most pro- 
foundly important since it teaches all the different professions. The major purpose of teacher education institutes is to generate competent and credentialed graduates who can work both in the Philippines and abroad. The goal of this study was to track the graduates of Wesleyan University-Philippines' College of Education in Cabanatuan City in order to assess their performance and the applicability of the college's curriculum to the job market. Its specific goal was to determine the alumni profile, their employment statistics, and the reasons that made them glad to be university graduates. This study also differs from the others since it focuses on the application of 21st-century skills learned at WUP College of Education in their employment.

\section{Methodology}

This study utilized the quantitative approach of research specifically the descriptive design. According to Creswell (2007) "descriptive research is concerned with conditions, practices, structures, differences or relationships that exist, opinions held, processes that are going on or trends that are evidently useful in presenting facts concerning the nature and the status of everything" (Mina, et al, 2019). The main tool used to gather data was researchers-made questionnaire which was face and content validated by the five experts in the field of education and research. The reliability of the instrument was established using Cronbach's alpha with a coefficient of 0.832 . The respondents of the study who were chosen purposively (Subia, 2018) were 142 alumni of Bachelor of Secondary and Elementary Education of the College of Education of Wesleyan University Philippines in Cabanatuan, Nueva Ecija, Philippines (Subia, Mangiduyos, \& Turgano, 2020). The respondents were picked based on the year they graduate (from 2000 to 2015) since they were the batches of alumni who were educated with 21st-century skills at WUP. Data gathered were analyzed using frequency, percentage, ranking, and weighted mean.

\section{Results and Discussion}

\subsection{Profile of the Respondents}

The majority of the respondents were females with 96 (67.6\%) while males were $46(32.4 \%)$. As to their batch, most of the respondents graduated last 2014 (35\% or $24.6 \%)$. It was followed by those who graduated in the year 2001 (14\% or 9.9\%) while the least were those who graduated in the year 2008 with 2 (1.4\%) respondents. It can also be noted that more respondents came from BEED (74\% or $52.1 \%$ ) than BSED ( $68 \%$ or $47.9 \%$ ). This means that most of the graduate respondents were females, graduated in the year 2014, and BEEd graduates.

\subsection{Employment Data}

Table 1 shows the employment data of the respondents in terms of the type of company/institution, employment status, occupation, place of work, length of years in current work, and monthly income. It can be gleaned on the table that 
Table 1. Employment data.

\begin{tabular}{ccc}
\hline Type of Company/Institution & Frequency & Percent \\
\hline Public & 104 & 73.2 \\
Private & 38 & 26.8 \\
Total & 142 & 100
\end{tabular}

\begin{tabular}{ccc}
\hline Employment Status & & \\
Permanent & 118 & 83.1 \\
Contractual & 18 & 12.7 \\
Self-employed & 6 & 4.2 \\
Total & 142 & 100 \\
\hline Occupation of the Respondents & & \\
Teacher/Instructor & 108 & 76.1 \\
Fire Officer & 4 & 2.8 \\
Social Worker & 3 & 2.1 \\
OFW & 7 & 4.9 \\
PNP & 2 & 1.4 \\
Nurse & 3 & 2.1 \\
Businessman & 3 & 2.1 \\
School Head (Principal/Administrator) & 8 & 5.6 \\
School Guidance Counselor & 4 & 2.8 \\
Total & 142 & 100.0 \\
\hline
\end{tabular}

\section{Place of Work}

\begin{tabular}{ccc} 
Local & 135 & 95.1 \\
Abroad & 7 & 4.9 \\
Total & 142 & 100.0 \\
\hline Length of Years in the Current Work & & \\
0 to 3 & 70 & 49.3 \\
4 to 7 & 22 & 15.5 \\
8 to 11 & 24 & 16.9 \\
12 to 15 & 22 & 15.5 \\
16 and above & 4 & 2.8 \\
Total & 142 & 100.0 \\
Monthly Income & & 4.2 \\
Below P10,000 & 6 & 42.3 \\
P10,000 to less than P20,000 & 60 & 36.6 \\
P20,000 to less than P30,000 & 52 & 7.0 \\
P30,000 to less than P40,000 & 10 & 6.3 \\
P40,000 to less than P50,000 & 9 & 3.5 \\
P50,000 and above & 5 & 100.0 \\
Total & 142 & \\
\hline
\end{tabular}


$104(73.2 \%)$ of the respondents are employed in public companies/institutions while $38(26.8 \%)$ are in the private. As to the respondents' employment status, $118(83.1 \%)$ are permanent, $18(12.7 \%)$ are contractual and $6(4.2 \%)$ are selfemployed. In terms of their current occupation and place of work, 108 (76.1\%) are teaching, $8(5.6 \%)$ are school heads and $4(2.8 \%)$ are school guidance counselors. This clearly demonstrates that 85 percent of respondents are employed in a field linked to the college course they took. This means that among Wesleyan University's education graduates, there was a high rate of employment in their field. Fire officers (2.8 percent), social workers (2.1 percent), OFWs (4.9 percent), PNPs (1.4 percent), Nurses (2.1 percent), and businessmen are among the 15 percent of respondents who chose other occupations. In terms of employment, 135 respondents work in the country, while only 7 work abroad. According to the data, the majority of the respondents are new to their current job, with 70 (49.3\%) having 0 to 3 years of experience and 22 (15.5\%) having 4 to 7 years. The majority of their monthly earnings are between P10,000 and P20,000. This data suggests that the number of years spent in the workforce is related to monthly earnings in some way. Because the majority of the responders are new to their jobs, they all have low salaries.

\subsection{Reasons for Being Hired in the Current Job}

Table 2 presents the reasons of the respondents for being hired in their current jobs.

When asked why they were hired, 48 (33.8 percent) of the respondents said they were hired because of the college's reputation. It was followed by being a walk-in candidate ( $30 \%$ or $21.1 \%$ ), and then scholastic standing (30\% or $21.1 \%)$. (16 or 11.3 percent). This indicates that the responders were hired due to the university's reputation and qualifications. This indicates that Wesleyan's reputation as an autonomous university and the College of Education's Level 3 accreditation status aided their alumni in obtaining current employment.

Table 2. Reasons for being hired.

\begin{tabular}{ccc}
\hline Reasons for Being Hired & Frequency & Percent \\
\hline Arranged by University's Job Placement & 12 & 8.5 \\
As Walk-in Applicant & 30 & 21.1 \\
Family Business & 6 & 4.2 \\
The reputation of the College & 16 & 11.3 \\
Response to Advertisement & 48 & 33.8 \\
Information from Neighbors and Friends \\
Job's Fair of Other Institutions
\end{tabular}




\subsection{Relevance of the 21st Century Skills of the Alumni in Their Current Work}

The respondents were asked if the 21st-century abilities they learned in college were relevant to their current jobs, and the results are shown in Table 3.

The majority of respondents agree that 21st-century abilities are useful in their current jobs. Interpersonal and collaborative abilities (extremely relevant-3.84), communication skills (very relevant-3.78), and problem identification, formulation, and solution (relevant-3.20) are the top three skills they have acquired and learned in the College of Education. This means that the respondents' training in collaborative activities, reciting and lecturing in front of a class, and problemsolving skills were all put to good use in their current jobs. Janet (2015) noted these 21st-century skills in her post about the top 10 attributes businesses seek in their employees. Communication abilities and problem-solving skills were two of the top ten credentials needed by employees to get the position, according to the article.

\subsection{What Makes You Proud as Alumnus/Alumna of WUP-College of Education?}

The respondents were asked why they are proud to be Wesleyan UniversityPhilippines, College of Education alumnus/alumna, and the results are displayed in Table 4.

Table 4 reveals that the item "the university provides outstanding education", which is ranked first among the reasons why respondents are proud Wesleyanians (124 or 86.11 percent). The university with independent status and strong accreditation is ranked second (62 or 43.7 percent). It is followed by a university with highly trained teachers ( 58 or 40.8 percent) and a university that prepares students for the actual world of work. The results clearly reveal that great education and good accreditation status are the key reasons why respondents are happy to have graduated from Wesleyan. Accreditation is a voluntary evaluation

Table 3. Relevance of the 21st century skills of the alumni in their current work.

\begin{tabular}{lcc}
\hline \multicolumn{1}{c}{ 21st Century Skills } & Weighted Mean & Verbal Description \\
\hline 1. Critical and System Thinking & 2.43 & Moderately Relevant \\
2. Communication Skills & 3.78 & Very Relevant \\
3. Accountability and Adaptability & 2.60 & Relevant \\
4. Self-Direction & 2.48 & Moderately Relevant \\
5. Problem Identification, Formulation, and Solution & 3.20 & Relevant \\
6. Interpersonal and Collaborative Skills & 3.84 & Very Relevant \\
7. Information and Media Literacy Skills & 2.61 & Relevant \\
8. Creativity and Intellectual Curiosity & 2.71 & Relevant \\
9. Social Responsibility & 2.73 & Relevant \\
\multicolumn{1}{c}{ Overall Weighted Mean } & 2.93 & Relevant \\
\hline
\end{tabular}


Table 4. The university provides outstanding education.

\begin{tabular}{|c|c|c|c|}
\hline What Makes You Proud as an Alumnus/Alumna of WUP & Frequency & Percent & Rank \\
\hline 1. The university offers quality education & 124 & 87.30 & 1 \\
\hline 2. The university has autonomous status & 62 & 43.70 & 2 \\
\hline 3. The university has highly qualified teachers & 58 & 40.80 & 3.5 \\
\hline 4. The university trains the students about the real world of work & 58 & 40.80 & 3.5 \\
\hline 5. The university taught the students to be good and spiritual & 54 & 38.00 & 5 \\
\hline $\begin{array}{l}\text { 6. The university helps students attain their dreams by } \\
\text { providing scholarships and other benefits }\end{array}$ & 40 & 28.20 & 6 \\
\hline $\begin{array}{l}\text { 7. The university trains the students to be catalysts for the } \\
\text { good of others }\end{array}$ & 16 & 11.30 & 7 \\
\hline 8. The university has well-known alumni & 6 & 4.20 & 9 \\
\hline 9. Other people respect and admire the university's graduates & 8 & 5.60 & 8 \\
\hline
\end{tabular}

procedure that higher education institutions go through in order to maintain educational quality criteria agreed upon by members of an accrediting body. Accreditation is crucial to students and graduates because it determines if a school meets or exceeds minimal quality criteria; it also aids employers in determining the validity of programs of study and whether a graduate is qualified. Employers frequently demand proof that applicants have graduated from a recognized institution or program (ACICS, 2010).

\section{Conclusion and Recommendation}

The nature of the alumni's jobs corresponded to their areas of expertise. Their time at the College of Education prepared them for work in the real world. The most significant 21st-century attributes needed in their current profession were judged to be interpersonal, collaboration, communication, and problem-solving skills. To increase the market competitiveness of WUP education graduates, all college disciplines should focus on developing and gaining various 21st skills, particularly those that will be utilized and needed in the workplace. Similarly, WUP's administration should persevere and make attempts to maintain its independent position and seek higher accreditation levels, as they aid university graduates in finding work.

\section{Conflicts of Interest}

The authors declare no conflicts of interest regarding the publication of this paper.

\section{References}

Accrediting Council for Independent Colleges and Schools (ACICS) (2010). http://www.acics.org/accreditation-about

Albina, A., \& Sumagaysay, L. (2020). Employability Tracer Study of Information Technolo- 
gy Education Graduates from a State University in the Philippines. Social Sciences and Humanities Open, 2, Article ID: 100055.

https://doi.org/10.1016/j.ssaho.2020.100055

Alvarez, M. (2020). Employment Trend of Graduates of Bachelor of Science in Business Administration Major in Marketing of the College of Business, Accountancy and Public Administration, Isabela State University. Journal of Critical Reviews, 7, 313-317. https://doi.org/10.31838/jcr.07.11.52

Aquino et al. (2016). Teacher Education Graduate Tracer Study from 2010 to 2014 in One State University in Batangas, Philippines. Asia Pacific Journal of Multidisciplinary Research, 3, 45-50.

Calma, R. (2019). A Tracer Study of the Bachelor of Science in Business Education Graduates of the Baliuag University from 2013 to 2015.

Creswell, J. W. (2007). Educational Research, Planning, Conducting and Evaluating Quantitative and Qualitative Research. Prentice-Hall.

Ismail, S., \& Mohammed, D. S. (2015). Employability Skills in TVET Curriculum in Nigeria Federal Universities of Technology. Procedia-Social and Behavioral Sciences, 204, 73-80. https://doi.org/10.1016/j.sbspro.2015.08.111

Janet, J. (2015). Top 10 Qualities and Skills Employers Are Looking for Employment North: LAC Media.

Menez, N. (2014). Tracer Study of the Masters in Business Administration (MBA) Graduates from 2008-2012. Asia Pacific Journal of Education, Arts and Sciences, 1, 14-18.

Mina, J. C., Barlis, P. T., Vega, N. C., \& Subia, G. S. (2019). Corporate Social Responsibilities of Selected Resorts in Cabanatuan City, Nueva Ecija, Philippines. Open Access Library Journal, 6, e5292. https://doi.org/10.4236/oalib.1105292

Orejana, A., \& Resurreccion, P. (2010). Tracer Study on the Graduates of the BSBA Program: An Input to Curricular Development. The Mindanao Forum.

Pontillas, V. V. (2018). Tracer Study on Bachelor of Science in Electrical Engineering Graduates of a Polytechnic College in the Philippines from 2007 to 2010. Asia Pacific Journal of Multidisciplinary Research, 6, 36-46.

http://www.apjmr.com/wp-content/uploads/2018/06/APJMR-2018.6.2.2.05.pdf

PSA Philippines Statistics Authority (2019). Employment Rate in January 2019 Is Estimated at 94.8 Percent.

https://psa.gov.ph/content/employment-rate-january-2019-estimated-948-percent

Ramirez, T. L., Cruz, L. T., \& Alcantara, N. V. (2014). Tracer Study of RTU Graduates: An Analysis. Journal of Arts, Science \& Commerce, 66, 66-76.

Ross, D. (2017). Empowering Our Students with 21st-Century Skills for Today. https://www.gettingsmart.com/2017/04/empowering-students-21st-century-skills

Subia, G. (2018). Comprehensible Technique in Solving Consecutive Number Problems in Algebra. Journal of Applied Mathematics and Physics, 6, 447-457. https://doi.org/10.4236/jamp.2018.63041

Subia, G. S., Mangiduyos, G. P., \& Turgano, J. B. D. (2020). Emergency Preparedness of Novo Ecijanos. Open Journal of Social Sciences, 8, 17-23. https://doi.org/10.4236/jss.2020.83003

Woya, A. (2019). Employability among Statistics Graduates: Graduates' Attributes, Competence, and Quality of Education. Education Research International, 2019, Article ID: 7285491. https://doi.org/10.1155/2019/7285491 